\section{Additional Records of Haplosporangium parvum in Mammals in Britain}

THE presence of a pulmonary fungus, Haplosporangium parvum Emmons and Äshburn', has been reported recently by McDiarmid and Austwick ${ }^{2}$ in moles, Talpa europaea, in England. The identity of large spherules, $100-390$ microns in diameter, found in the lungs was confirmed by culture. 'These findings are of particular interest to me as they help solve a parasitological enigma encountered in Britain in 1945.

While on military duty in England, I examined a considerable number of small mammals which I trapped between October 22, 1944, and March 5, 1945 , on the chalk downs near Camp Blandford, two miles north-east of Blandford, Dorset. 'The lungs of some of these mammals contained hard, discrete spherules ranging up to 250 microns in diameter. Each spherule, which was visible to the naked eye, could be removed easily with forceps. It appeared to have two walls and was filled with 'cells' resembling oil globules. When pressure was applied, it cracked audibly. In a few specimens the lung tissue surrounding a spherule was cloudy in appearance, possibly fibrotic. Some animals were infested with a large number of the eyst-like objects.

Notes made at the time (January 17,1945 ) read as follows: "Today I saw Dr. H. A. Baylis of the British Museum to whom I had sent parasitic worms for identification. $\mathrm{He}_{\Theta}$ is particularly interested in the cysts from the lungs of Clethrionornys. He cannot determine what causes them. He expected to find trematode larvæ within but was unable to demonstrate such. According to him, the interior of a cyst is composed of nothing but oil globules; therefore, when a cyst is sectioned for microscopic examination it appears to be empty. Lungs which Baylis cleared show how evenly and thickly the cysts are distributed through the tissue. As an alternative to trematode larvæ, Baylis thought the cysts might have been caused by mites or pollen grains. In favour of the mite theory he had noted in some instances a suggestion of spines within a cyst. However, the hard shell is composed of two layers : an outer one formed by the lung tissue and an inner one presumably formed by something within the cyst".

This experience closely parallels that of American workers when the large form of Haplosporangium was encountered and described as an undetermined parasite ${ }^{3}$.

I have since become familiar with Haplosporangium in North American rodents and am certain that the spherulos observed in the lungs of rodents in England are the same. The work of McDiarmid and Austwick (l.c.) tends to confirm this identification. The lung specimens from Camp Blandford were left with Dr. Baylis. In reply to a recent inquiry, officials of the British Museum stated that Dr. Baylis had retired and the specimens could not be readily found.

Mammals examined and infections detected at Camp Blandford were as follows: Apodemus sylvaticus, sixty (one infected); Apodemus flavicollis, three (one infected) ; Clethrionomys glareolus, thirtyeight (nine infected); Sorex araneus, thirteen; Sorex minutus, six; Microtus agrestis, one; Mus musculus, two; Talpa europaea, one ; and Erithacus rubecula, one.

These records extend the host range of Haplosporangium parvum in Britain to three additional mammal species. The parasite is not yet known from man.
This communication was prepared at the suggestion of, and with assistance from, Dr. William L. Jellison, of the United States Public Health Service.

Department of Zoology,

Lioyd Tevis, JUN.

University of California,

Davis, Califormia. Oct. 17.

${ }^{1}$ Emmons, C. W., and Ashburn, L. L., Public Health Rep., 57, 1715 (1942).

${ }^{2}$ McDiarmid, A., and Austwick, P. K. C., Nature, 174, 843 (1954).

${ }^{3}$ Jellison, William L., Proc. Helmin. Soc. Wash., 14, 75 (1947).

\section{Attempts at Hybridization of Chickens and Turkeys which are Tolerant of Each Others' Antigens}

IN a recent communication in Nature, Simonsen ${ }^{1}$ described experiments which showed that injection of turkey blood into chick embryos both delayed the appearance of natural agglutinins and suppressed the formation of immune agglutinins when the young birds were injected with turkey blood some weeks after hatching. Moreover, turkeys injected as embryos with chicken blood proved to be susceptible to infection with Rous sarcoma virus at an age by which this species is normally resistant to it. Tests relating to his third purpose, namely, to see whether a sexual cross between species, which is not normally possible, could be made so by acquired tolerance, are summarized here. They do not, however, provide any evidence that the tolerant birds were more able to produce hybrid offspring than normal ones. Both Warren and Scott ${ }^{2}$ and Quinn, Burrows and Byerly ${ }^{3}$ obtained at least slight development in a proportion of the eggs in both reciprocal crosses between normal turkeys and chickens, although only about 1 per cent of the chicken eggs proved fertile.

In making the reciprocal crosses, semen was collected from the male birds, and the fomales were inseminated by the methods of Burrows and Quinn ${ }^{4}$. At first only semen from the blood-donor was used ; later, in order to increase the volume per hen, that from several males was pooled. All eggs laid from one day after the first insemination to ten days after the last were incubated.

There were seven experimental Brown Leghorn hens which had been injected intravenously with $0.05-0.2 \mathrm{ml}$. of turkey blood on the ninth, tenth or eleventh day of incubation. Three of these had been immunized with turkey blood after hatching until their tolerance broke down. Five additional birds had been injected under the blastoderm, either before incubation or after one day in the incubator; they had received no post-hatching treatment. These twelve hens were inseminated from one to eight times each, the average being about four times, usually at intervals of three to four days. The volume of semen per insemination ranged from 0.025 to $0.1 \mathrm{ml}$. per hen, $0.1 \mathrm{ml}$. being most frequent. In all, eighty-two eggs were set : the minimum per hen was one (one hen only); the maximum, eighteen. The eggs were candled after five to seven days incubation when, without exception, they appeared 'clear' ; forty-three were opened and it was confirmed that no fertilization had occurred.

Only three experimental turkeys and two controls were available. Two of the experimental birds had received intravenously $0.1 \mathrm{ml}$. of blood from a Brown Leghorn cock on the thirteenth day of incubation; the third had received the same quantity on the twentieth day. All five birds had been immunized 